\title{
Paneth cell $\alpha$-defensins and enteric microbiota in health and disease
}

\author{
Kiminori NAKAMURA ${ }^{1}$, Naoya SAKURAGI ${ }^{1}$, Akiko TAKAKUWA ${ }^{1,2}$ and Tokiyoshi AYABE ${ }^{1 *}$ \\ ${ }^{1}$ Department of Cell Biological Science, Graduate School of Life Science, Faculty of Advanced Life Science, Hokkaido University, \\ Kita-21, Nishi-11, Kita-ku, Sapporo, Hokkaido 001-0021, Japan \\ 2 Department of Nutrition, Faculty of Nursing and Nutrition, Tenshi College, 3-1-30 Higashi, Kita-13, Higashi-ku, Sapporo, Hokkaido \\ 065-0013, Japan
}

Received August 20, 2015; Accepted October 25, 2015; Published online in J-STAGE November 26, 2015

\begin{abstract}
Antimicrobial peptides are major effectors of innate immunity of multicellular organisms including humans and play a critical role in host defense, and their importance is widely recognized. The epithelium of the intestine is the largest surface area exposed to the outer environment, including pathogens, toxins and foods. The Paneth cell lineage of intestinal epithelial cells produces and secretes $\alpha$-defensin antimicrobial peptides and functions in innate enteric immunity by removing pathogens and living symbiotically with commensal microbiota to contribute to intestinal homeostasis. Paneth cells secrete $\alpha$-defensins, HD5 and HD6 in humans and cryptdins in mice, in response to bacterial, cholinergic and other stimuli. The $\alpha$-defensins have selective activities against bacteria, eliciting potent microbicidal activities against pathogenic bacteria but minimal or no bactericidal activity against commensal bacteria. Therefore, $\alpha$-defensins regulate the composition of the intestinal microbiota in vivo and play a role in homeostasis of the entire intestine. Recently, relationships between dysbiosis, or abnormal composition of the intestinal microbiota, and diseases such as inflammatory bowel disease and lifestyle diseases including obesity and atherosclerosis have been reported. Because $\alpha$-defensins regulate the composition of the intestinal microbiota, Paneth cells and their $\alpha$-defensins may have a key role as one mechanism linking the microbiota and disease.
\end{abstract}

Key words: Paneth cell, $\alpha$-defensin, intestinal microbiota, innate immunity, dysbiosis, inflammatory bowel disease, lifestyle disease

\section{INTRODUCTION}

Antimicrobial peptides are gene-encoded effectors in innate immunity of multicellular organisms, from plants and insects to animals including humans, and generally they are cationic small peptides with broad microbicidal activities against bacteria, fungi, protozoa, and certain viruses [1-3]. More than 1,000 antimicrobial peptides have been found in nature. Among mammals, defensins and cathelicidins are the two major families [4-6].

The intestine absorbs nutrients necessary for life, and it also prevents invasion of pathogens, thus contributing to mucosal immunity. Intestinal epithelial cells occupy

\footnotetext{
*Corresponding author. Mailing address: Tokiyoshi Ayabe, Department of Cell Biological Science, Faculty of Advanced Life Science, Hokkaido University, Kita-21, Nishi-11, Kita-ku, Sapporo, Hokkaido 001-0021, Japan. Phone: +81-11-706-9049, Fax: +81-11-706-9053. E-mail: ayabe@sci.hokudai.ac.jp (C)2016 BMFH Press

This is an open-access article distributed under the terms of the Creative Commons Attribution Non-Commercial No Derivatives (bync-nd) License $<$ http://creativecommons.org/licenses/by-nc-nd/4.0/>.
}

the front line of the human interface with the external environment, which is under constant stimulation by foods and microbes, so they are important in a number of ways, including in nutrient absorption, regeneration and mucosal immunity $[7,8]$. The epithelium of the intestine is the largest body surface exposed chronically to various pathogens, toxins, commensal microbiota and foods. More than $1 \times 10^{14}$ bacteria live in the human intestinal lumen, and the normal intestinal microbiota is comprised of a huge number of symbiotic microorganisms [9, 10]. The epithelial cells that line the small intestine are organized into villi and crypts and consists of four major lineages of terminally differentiated cells: columnar cells, enteroendocrine cells, goblet cells, and Paneth cells. These cell lineages are generated by cells termed crypt base columnar (CBC) stem cells, which reside at the bottom of the crypt, adjacent to Paneth cells [11]. Intestinal epithelial cells, except Paneth cells, migrate toward the top of the villi as they differentiate, and they are renewed every three to four days [12]. In contrast, Paneth cells reside at the bottom of small intestinal crypts, establish physical contact with $\mathrm{CBC}$ stem cells, 
(A)

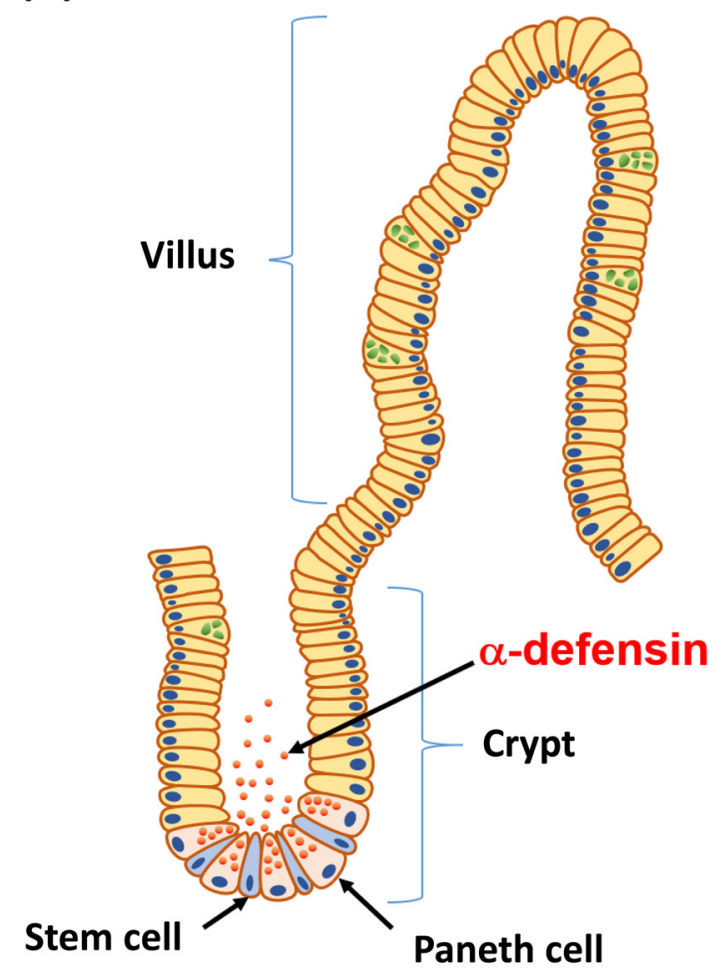

(B)

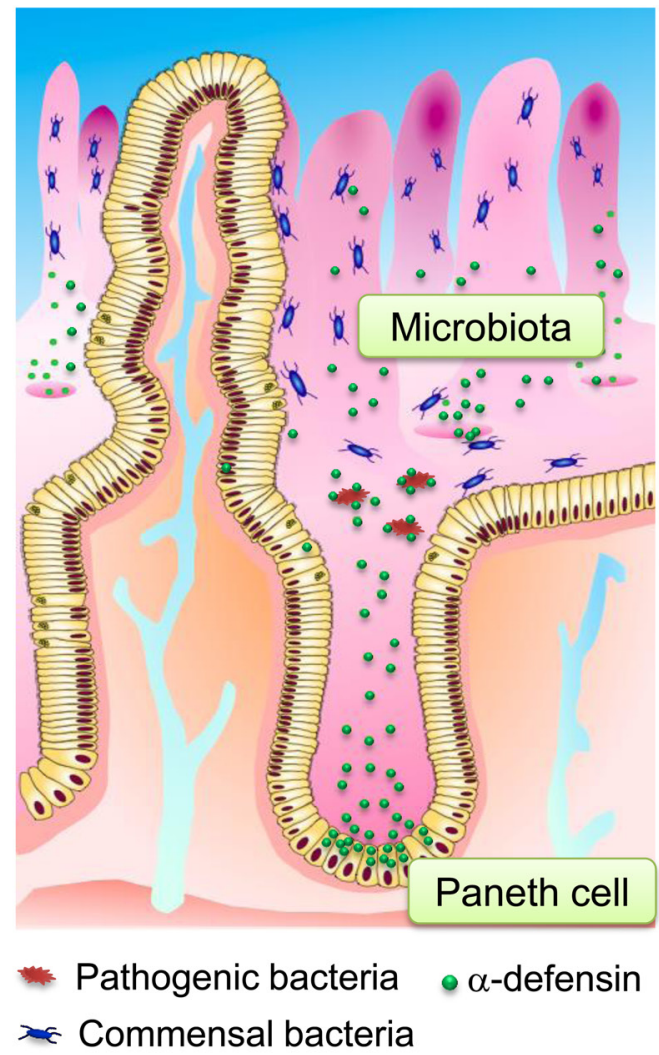

Fig. 1. Stem cells and Paneth cells, their $\alpha$-defensins and the microbiota in the small intestine.

(A) Small intestinal epithelial cells form villus and crypt structures. Paneth cells and stem cells reside with physical contact at the bottom of crypt and create a stem cell niche. (B) Paneth cells secrete $\alpha$-defensins in response to bacterial and various stimuli and contribute to innate enteric immunity as well as to regulation of the intestinal microbiota.

and live 24 days or more [13, 14] (Fig. 1A).

Recently, relationships between the intestinal microbiota and various diseases have become evident. One of the reasons for this is the rapid advances in metagenome analyses of the microbiota, which can detect and quantitate even non-culturable bacteria [15]. Similarly, the importance of antimicrobial peptides in regulating the microbiota as major effectors in innate immunity has also been widely recognized recently [16-20]. Paneth cells are the only intestinal epithelial cells expressing enteric $\alpha$-defensins and secreting them onto the intestinal luminal surface in response to certain stimuli [16-18]. It is known that Paneth cell $\alpha$-defensins are directly involved in not only removing pathogens but also in establishing symbiosis with the normal intestinal microbiota $[19,20]$. In this review, we summarize recent advances in innate immunity related to Paneth cells and their $\alpha$-defensins and consider possible links between the microbiota and disease.

\section{PANETH CELLS, A LINEAGE OF INTESTINAL EPITHELIAL CELLS, SECRETE $\alpha$-DEFENSINS}

The intestine faces the outer environment with epithelial cells, which absorb nutrients, water and minerals while preventing invasion of pathogens or toxins by establishment of a physical barrier as well as innate immune responses. The intestinal cavity is an outside at an inside of the human body. It has long been known that the number of bacteria comprising the microbiota in the small intestinal is much lower than that in the large intestine. To explain this, the contributions of the digestive juice, mucus and bowel peristalsis have been considered as physiologic factors in the small intestine, as has the contribution of the adaptive immune system including IgA and lymphocytes in Peyer's patches. In addition, the contribution of Paneth cells and secreted $\alpha$-defensins in the innate enteric immunity has been recognized, as their roles have been clarified. In the innate immunity, recognition of microbes by Toll- 
like receptors and other pattern-recognition receptors on host cells occurs first [21, 22]. Immediately after this step, microbicidal antimicrobial peptide synthesis and/ or mobilization are triggered in affected epithelia or neutrophils, and their secretion by epithelia is activated. Antimicrobial peptides comprised of 18-45 amino acids in multicellular organisms are microbicidal cationic peptides and are capable of killing a variety of pathogens including bacteria, fungi, protozoa and viruses [3]. In mammals, defensins and cathelicidins are two major families of antimicrobial peptides. Among them, only $\alpha$-defensins are constitutively expressed in intracellular granules of Paneth cells and secreted immediately in response to bacteria. Mammalian $\alpha$-defensins are 3-4 $\mathrm{kDa}$ cationic peptides with 6 cys residues that form invariant 3 disulfide bonds [6, 23-25]. In Paneth cells, HD5 and HD6 in humans and cryptdins comprised of six major isoforms, cryptdin- 1 to cryptdin- 6 , in mice are the major constituents of the intracellular granules $[16$, 17, 26, 27]. Mouse cryptdins are processed by matrix metalloproteinase 7 (MMP7) also called matrilysin, to the active form during granulogenesis [28]. In contrast, human Paneth cell $\alpha$-defensins, HD5 and HD6, are packaged as pro- $\alpha$-defensin and processed by one or more isoforms of trypsin during or after secretion [29]. Both in mouse and human Paneth cells, mature $\alpha$-defensin segments are in the oxidized state so that internal digestion is prevented.

Paneth cell $\alpha$-defensins are the major antimicrobial peptides produced and released by the small intestinal epithelium. As unique exceptions, it was reported that metaplastic Paneth cells found in the Helicobacter pylori infected stomach and in the colon in patients with ulcerative colitis produce $\alpha$-defensins [30, 31]. Prevention of infection with pathogens by secretion of microbicidal $\alpha$-defensins in immediate response to bacterial, cholinergic or other stimuli was revealed as an important role of Paneth cells in mucosal immunity [18, 32-39] (Fig. 1B). Paneth cells also secrete other antimicrobial peptides, such as $\operatorname{Reg} 3 \gamma$, and antimicrobial proteins including lysozyme and secretory phospholipase $\mathrm{A}_{2}$ [40, 41]. Furthermore, Paneth cells are known to create a specific microenvironment called the stem cell niche together with CBC stem cells [42-47]. In the niche, Paneth cells produce growth factors and Wnt signaling molecules that lead to Wnt on and Notch off, which are delivered to $\mathrm{CBC}$ cells and induce differentiation of specific epithelial cell lineages. Therefore, Paneth cells function both in innate enteric immunity and in regeneration/differentiation of epithelial cells in the small intestine. They elicit even more multifunctional roles in chemotaxis and metabolism [48-50]. However, it must be emphasized that Paneth cells contribute professionally to host defense by secreting $\alpha$-defensins. The fact that Paneth cells, which are capable of rapidly responding to microbial invaders, reside back to back with stem cells in the intestine may be very important.

\section{a-DEFENSINS ELIMINATE PATHOGENS BUT DO NOT KILL COMMENSAL BACTERIA TO MAINTAIN THE INTESTINAL ENVIRONMENT}

Intestinal epithelial cells absorb nutrients and water and at same time create potent barriers against microbes including pathogens. When pathogens try to invade the host, innate immune mechanisms of intestinal epithelial cells are induced or activated immediately. Since potent microbicidal activities of cryptdins, mouse $\alpha$-defensins, against pathogenic bacteria were reported, the importance of $\alpha$-defensins in mucosal immunity has been widely recognized [51-53]. MMP7 processes and activates pro- $\alpha$-defensins, pro-cryptdins, in mouse Paneth cells. MMP7-null mice lack activated cryptdins in Paneth cell granules, accumulating only inactive, non-microbicidal precursors. When mice were challenged orally with Escherichia coli, significantly greater numbers of surviving bacteria were recovered from the MMP-7-null mouse intestine as compared with the numbers recovered from wild type mice. Furthermore, when Salmonella typhimurium was orally administered, the MMP7-null mouse was more susceptible to systemic disease [28]. This was among the first evidence showing that antimicrobial peptides are involved in mammalian host defense in vivo. Paneth cells at the bottom of small intestinal crypts of the mouse secrete intracellular granules rich in cryptdins in immediate response to various stimuli including carbamylcholine, Gram-positive and Gram-negative bacteria, lipopolysaccharide, and muramyl dipeptide [18]. Secreted cryptdins kill pathogenic bacteria to contribute to innate immunity. The expression of a human Paneth cell $\alpha$-defensin transgene, i.e., HD5, in mouse Paneth cells augmented mouse innate enteric immunity and conferred immunity against oral Salmonella infection by reducing bacterial numbers in the intestinal lumen and in feces, decreasing bacterial translocation and promoting high survival rates after lethal Salmonella challenge [54]. These results demonstrated that Paneth cell $\alpha$-defensins contribute actively to enteric host defense in vivo. In addition, deficiency of another antimicrobial peptide in mouse Paneth cells, Reg3 $\gamma$, disrupts the physical barrier function of intestinal epithelial cells [55].

It has been known that the growth of germ-free mice is 
poor and that these mice are immature or even deficient in mucosal immunity [56]. The commensal microbiota is able to elicit maturation of enteric mucosal immunity, including development of Peyer's patches, increasing IgA production; differentiation of regulatory $\mathrm{T}$ cells; and induction of certain antimicrobial peptides [10, 57-69]. Therefore, commensal bacteria are necessary for development and stability of the enteric immune response. It has been revealed that $\alpha$-defensins not only kill pathogens but also contribute to intestinal homeostasis by maintaining the composition of the normal intestinal microbiota. For example, the ileal microbiota in MMP7deficient mice, which lack activated cryptdins, contained a significantly higher percentage of Firmicutes and a significantly lower percentage of Bacteroides compared with wild-type mice [19]. Furthermore, in DEFA5+/+ mice, which express the human $\alpha$-defensin HD5 transgene in Paneth cells, the microbiota composition in the small intestine was dramatically different from that of the wildtype strain, with significantly decreased Firmicutes and significantly increased Bacteroidetes [54]. Of the six most abundant mouse Paneth cell $\alpha$-defensins, cryptdin 4 is the most potent microbicide. Masuda et al. revealed that oxidized cryptdin 4 with three disulfide bonds shows potent bactericidal activity against pathogenic bacteria but no or minimal bactericidal activity against commensal bacteria such as Bifidobacterium bifidum, Lactobacillus casei and Bacteroides fragilis [20]. In contrast, reduced cryptdins, which have no disulfide bonds, kill both pathogenic and commensal bacteria. These results suggest that Paneth cell $\alpha$-defensins possess disulfide bond-dependent bactericidal activities and play a role in regulating the composition of the intestinal microbiota to maintain the intestinal environment (Fig. 2). It has been shown that Crp4 permeabilized the phospholipid bilayer and that the activity was dependent on the membrane composition [70]. It has also been reported that depolarization of the membrane potential in some noncommensal bacteria occurs via cryptdin4 [20]. However, the precise bactericidal mechanisms of native Crp4 have yet to be fully elucidated and may be bacteria dependent. Furthermore, a recent report clarified that activated cryptdins, which have been previously thought to play a role only in the small intestine, are present in the luminal content of the cecum and colon [71, 72]. Although the effects of $\alpha$-defensins on the composition of the colonic microbiota remain unknown, it is possible that Paneth cell $\alpha$-defensins may influence the microbiota of the distal gut. However, a lack of sensitive assays to quantify $\alpha$-defensins released into the intestinal lumen has limited efforts to establish a relationship between

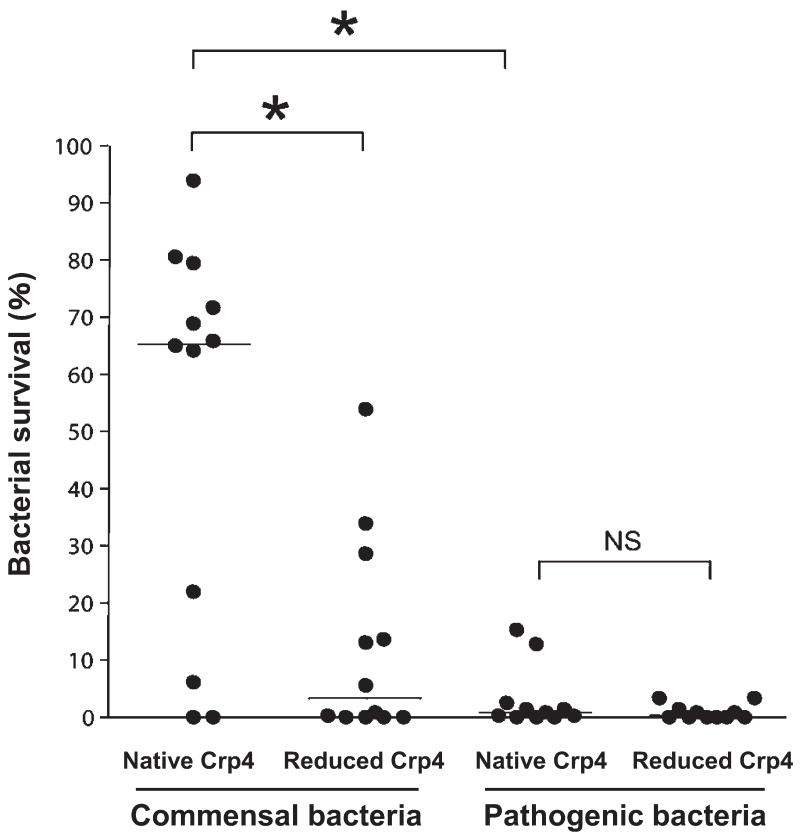

Fig. 2. Bactericidal activities of native (oxidized) cryptdin 4 and reduced cryptdin 4 against commensal bacteria and pathogenic bacteria.

The survival rates of twenty commensal bacteria and eleven pathogenic bacteria when each bacterium was exposed to either native cryptdin 4 or reduced cryptdin 4 are shown. Cryptdins regulate the intestinal microbiota by eliciting potent bactericidal activities against pathogenic bacteria and less potent bactericidal activities against most commensal bacteria. (Modified from the study of Masuda et al. [20].) $* \mathrm{p}<0.05$. NS: not significant.

levels of secreted $\alpha$-defensin and disease. Nakamura et al. established a highly sensitive and specific sandwich ELISA for cryptdins recently [73]. The concentration of cryptdin 4 was measured throughout the enteric lumen, and it was confirmed that the concentrations of secreted cryptdin 4 increases along the proximal to distal axis, with the highest levels in the distal ileum. In addition, the concentration of cryptdin 4 was determined in the luminal contents of the cecum and colon, where Paneth cells are absent. This is consistent with a previous finding indicating that processed cryptdins were recovered from the luminal contents of the colon and cecum, which was confirmed by both bactericidal assays and gel electrophoresis [73]. Therefore, secreted $\alpha$-defensins may influence the intestinal microbiota not only in the small intestine but also in the colon. By testing fecal samples, the ELISA revealed an overall deficiency of this secreted $\alpha$-defensin in the intestine of the IL10-null mouse, a mouse model of colitis, which is consistent with decreased $\alpha$-defensin levels reported in CD patients [74]. 
Furthermore, the ability of this ELISA system to quantify total secreted cryptdin 4 in feces may contribute to a better understanding of the relation of luminal $\alpha$-defensin levels to diverse diseases, including inflammatory bowel disease (IBD), infectious diseases, diabetes and obesity.

\section{PANETH CELL DISRUPTION INDUCES DYSBIOSIS AND IS LINKED TO CERTAIN DISEASES}

Dysbiosis, disruption of the composition of the intestinal microbiota, has been associated not only with infectious diseases but also with the pathogenesis and pathophysiology of diverse diseases. Because of recent rapid advances in methods of genetic analysis of microbes such as terminal-restriction fragment length polymorphism (T-RFLP) analysis and metagenomic analysis targeted at bacterial $16 \mathrm{~S}$ rRNA in addition to the gold-standard culture methods, the possible relationship between the microbiota and diseases has become a major topic in the biomedical sciences. For example, the relative proportion of Bacteroidetes and Firmicutes in obese people differs markedly from that of lean individuals, suggesting that obesity is associated with a particular microbial component $[75,76]$. Since then, the number of reports regarding the composition of the microbiota determined by metagenomics analysis and diverse diseases has grown continuously. Such diseases include type II diabetes mellitus [77], metabolic syndrome [78, 79], atherosclerosis [80], nonalcoholic steatohepatitis [81, 82], autism [83], liver cirrhosis [84], liver cancer [85], IBD [86-88] and more [89, 90]. Moreover, fecal microbiota transplantation has therapeutic efficacies for recurrent Clostridium difficile infection, indicating that microbiota alteration also may be beneficial for other diseases such as IBD and metabolic syndrome [91]. However, the mechanisms underlying how dysbiosis is linked to these diseases have yet to be fully determined. We are currently working on a simplified model to understand possible mechanisms of the "intestinal environment," which we hypothesized is associated with three factors: Paneth cell $\alpha$-defensins, the intestinal microbiota and dietary factors (Fig. 3).

Mice lacking IL10 or IL2 induce colitis spontaneously; however, these mice have no or mild colitis if they are kept under germ-free conditions [92-94]. It is common for patients with IBD to frequently suffer local or systemic infection with bacterial overgrowth or dysbiosis [95]. The microbiota of patients with Crohn's disease (CD) shows less diversity of Firmicutes than healthy subjects [86]. CD is a young-onset IBD that affects the entire digestive tract, especially the small intestine and causes

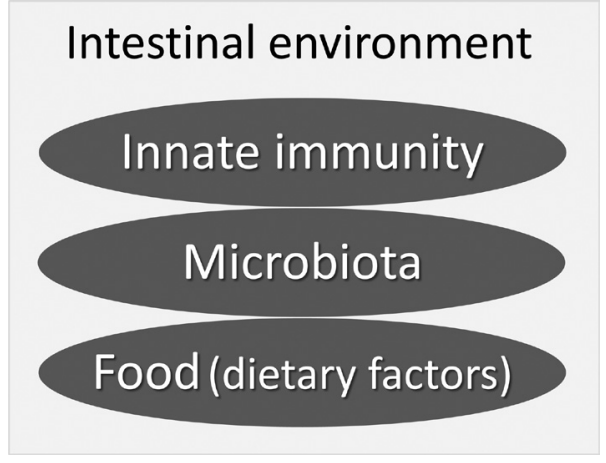

Fig. 3. Factors affecting the intestinal environment: a working hypothesis.

A simplified model: Three factors, innate immunity, microbiota and food, cross talk with each other and contribute to the intestinal environment in both the short and long term. Innate Immunity: Paneth cell $\alpha$-defensins act as major effectors in innate immunity. Microbiota: Commensal bacteria form the normal intestinal microbiota. Food (dietary factors): Food and dietary factors act as orally administered extrinsic factors.

transmural enteritis, longitudinal ulcers and stenosis of the intestine. Many CD patients suffer relapse frequently after achieving remission through therapy, and the disease persists chronically, so the patients' quality of life is poor and a big problem. Although our understanding of the pathogenesis of $\mathrm{CD}$ is still incomplete, it has been revealed that some of the many $\mathrm{CD}$ risk factors and susceptibility genes are related to recognition receptors of pathogen-associated molecular patterns, autophagy, molecular chaperones and ER stress response, many of which are expressed in Paneth cells. Furthermore, genetic defects of NOD2 [96-100] or genes related to autophagy and ER stress affect Paneth cells selectively and contribute to IBD pathogenesis. In mice with genetic defects for the autophagy gene, Atg16L1, Paneth cells showed morphological abnormalities and were defective in secretion [101]. It was also reported that such Paneth cell disruption is dependent both on the mutated Atg16L1 and on infection with a specific strain of norovirus as a socalled second hit [102]. This is taken as a clear example showing that a combination of both a genetic risk factor and an environmental factor, such as a specific infectious agent, is necessary for onset of IBD. Furthermore, deletion of Xbpl leads to an abnormal unfolded protein response and induces Paneth cell apoptosis and severe ileitis in the mouse [103]. Also, mice with deletion of the Anterior Gradient 2 gene, a protein disulfide isomerase, have goblet cells depleted of Mucin 2, a disrupted Paneth cell morphology and severe terminal ileitis and colitis induced by ER stress [99, 104-106]. These results 
indicate that genetic defects that lead to disruption of Paneth cell homeostasis could weaken innate enteric immunity by reducing $\alpha$-defensin production and secretion. In addition, importantly, Paneth cell disruption could also eliminate or modify the stem cell niche, which is necessary for regeneration and differentiation of the entire intestinal epithelial monolayer via communication between Lgr5-positive CBC stem cells and Paneth cells to maintain small intestinal integrity [44].

Reduced mRNA expression of intestinal tissue HD5 compared with healthy subjects has been reported in some CD patients [107]. In addition, the HD5 precursor was reported to be reduced in certain CD patients [108]. Reduced pro-HD5 was sensitive to degradation by trypsin, a processing enzyme for HD5, and resulted in a diminished production of mature HD5. These results suggest that potent protease resistance of $\alpha$-defensins due to their three disulfide bonds may contribute to the maintenance of a healthy intestinal environment and the pathogenesis of diseases such as IBD. Changes in Paneth cell $\alpha$-defensin expression and/or secretion may contribute to $\mathrm{CD}$, and changes in the intestinal microbiota may mediate the pathogenesis [109]. To test this, it is important to monitor sequential changes in the levels of $\alpha$-defensins secreted into the intestinal lumen. Secreted cryptdin4 levels in feces were reduced significantly in IL10-null mice compared with wild type mice [72], suggesting that diminished Crp4 secretion led to dysbiosis. Failure of cryptdin production and/or cryptdin secretion in IL10-null mice may contribute to the reduction in secreted cryptdin. Whether or not decreased production or secretion of $\alpha$-defensins in CD patients is an independent event in $\mathrm{CD}$ or secondary event due to severe inflammation with massive loss of small intestinal epithelia, including Paneth cells, is still controversial.

Paneth cells are selectively depleted during graftversus-host disease (GVHD), resulting in a marked reduction in expression and secretion of $\alpha$-defensins, which selectively kill pathogenic bacteria while preserving the commensal population [110]. In the mouse GVHD model, the diversity of the intestinal microbiota is lost, an overwhelming expansion of Escherichia coli occurs, and the GVHD mice die of $E$. coli septicemia [110]. These results revealed a direct link between Paneth cell loss in GVHD and a dramatic shift in the microbiota composition from commensals to specific pathogens. Thus, Paneth cell depletion with subsequent loss of $\alpha$-defensins leads to vital dysbiosis $[111,112]$. Furthermore, obese subjects reportedly show increased HD5 mRNA expression and decreased HD5 protein in comparison with healthy subjects [113].
Although it is not yet clear whether Paneth cells of obese people actually secrete less $\alpha$-defensins relative to lean subjects, $\alpha$-defensins and the intestinal microbiota composition may have a pathophysiological link with obesity. In addition, ischemia/reperfusion injury of the small intestine [106] and Toxoplasma infection [114] in mice have been shown to induce Paneth cell depletion, leading to dysbiosis and severe infection.

From recent advances regarding the roles of Paneth cells and their $\alpha$-defensins, a consensus view has emerged that suggested that a reduction or excess of $\alpha$-defensins or disruption of the $\alpha$-defensin tertiary structure results in dysbiosis due to Paneth cell dysfunction. Paneth cells also have a critical role in establishing the stem cell niche contributing directly to epithelial regeneration and differentiation [115]. Thus, we suggest that varied Paneth cell abnormalities and their production and release of $\alpha$-defensins are associated with various diseases including infectious diseases, IBD and obesity and that they may also contribute to morbidity in other diseases by failing to maintain eubiosis, thereby disrupting the intestinal environment. Further studies are necessary to understand Paneth cell biology and to prove links among Paneth cells, the intestinal microbiota and diverse diseases.

\section{ACKNOWLEDGEMENTS}

This work was supported by Grants-in-Aid for Scientific Research from the Japan Society for the Promotion of Science (for KN and NS) and the Ministry of Education, Culture, Sports, Science and Technology of Japan (for TA). This work was also partially supported by the Center of Innovation Program of the Japan Science and Technology Agency (for KN).

\section{REFERENCES}

1. Steiner H, Hultmark D, Engström A, Bennich H, Boman HG. 1981. Sequence and specificity of two antibacterial proteins involved in insect immunity. Nature 292: 246-248. [Medline] [CrossRef]

2. Selsted ME, Harwig SS, Ganz T, Schilling JW, Lehrer RI. 1985. Primary structures of three human neutrophil defensins. J Clin Invest 76: 1436-1439. [Medline] [CrossRef]

3. Zasloff M. 2002. Antimicrobial peptides of multicellular organisms. Nature 415: 389-395. [Medline] [CrossRef]

4. Ganz T. 2003. Defensins: antimicrobial peptides of innate immunity. Nat Rev Immunol 3: 710-720. [Medline] [CrossRef]

5. Tomasinsig L, Zanetti M. 2005. The cathelicidinsstructure, function and evolution. Curr Protein Pept Sci 
6: 23-34. [Medline] [CrossRef]

6. Selsted ME, Ouellette AJ. 2005. Mammalian defensins in the antimicrobial immune response. Nat Immunol 6: 551-557. [Medline] [CrossRef]

7. Thorburn AN, Macia L, Mackay CR. 2014. Diet, metabolites, and "western-lifestyle" inflammatory diseases. Immunity 40: 833-842. [Medline] [CrossRef]

8. Kagnoff MF. 2014. The intestinal epithelium is an integral component of a communications network. J Clin Invest 124: 2841-2843. [Medline] [CrossRef]

9. Mitsuoka T. 2014. Establishment of intestinal bacteriology. Biosci Microbiota Food Health 33: 99-116. [Medline] [CrossRef]

10. Lozupone CA, Stombaugh JI, Gordon JI, Jansson JK, Knight R. 2012. Diversity, stability and resilience of the human gut microbiota. Nature 489: 220-230. [Medline] [CrossRef]

11. Snippert HJ, van der Flier LG, Sato T, van Es JH, van den Born M, Kroon-Veenboer C, Barker N, Klein AM, van Rheenen J, Simons BD, Clevers H. 2010. Intestinal crypt homeostasis results from neutral competition between symmetrically dividing Lgr5 stem cells. Cell 143: 134-144. [Medline] [CrossRef]

12. McKernan DP, Egan LJ. 2015. The intestinal epithelial cell cycle: uncovering its 'cryptic' nature. Curr Opin Gastroenterol 31: 124-129. [Medline] [CrossRef]

13. Potten CS. 1975. Kinetics and possible regulation of crypt cell populations under normal and stress conditions. Bull Cancer 62: 419-430. [Medline]

14. Buczacki SJ, Zecchini HI, Nicholson AM, Russell R, Vermeulen L, Kemp R, Winton DJ. 2013. Intestinal label-retaining cells are secretory precursors expressing Lgr5. Nature 495: 65-69. [Medline] [CrossRef]

15. Weinstock GM. 2012. Genomic approaches to studying the human microbiota. Nature 489: 250-256. [Medline] [CrossRef]

16. Ouellette AJ, Miller SI, Henschen AH, Selsted ME. 1992. Purification and primary structure of murine cryptdin-1, a Paneth cell defensin. FEBS Lett 304: 146-148. [Medline] [CrossRef]

17. Ouellette AJ, Hsieh MM, Nosek MT, Cano-Gauci DF, Huttner KM, Buick RN, Selsted ME. 1994. Mouse Paneth cell defensins: primary structures and antibacterial activities of numerous cryptdin isoforms. Infect Immun 62: 5040-5047. [Medline]

18. Ayabe T, Satchell DP, Wilson CL, Parks WC, Selsted ME, Ouellette AJ. 2000. Secretion of microbicidal $\alpha$-defensins by intestinal Paneth cells in response to bacteria. Nat Immunol 1: 113-118. [Medline] [CrossRef]

19. Salzman NH, Hung K, Haribhai D, Chu H, KarlssonSjöberg J, Amir E, Teggatz P, Barman M, Hayward M, Eastwood D, Stoel M, Zhou Y, Sodergren E, Weinstock GM, Bevins CL, Williams CB, Bos NA. 2010. Enteric defensins are essential regulators of intestinal microbial ecology. Nat Immunol 11: 76-83. [Medline]
[CrossRef]

20. Masuda K, Sakai N, Nakamura K, Yoshioka S, Ayabe T. 2011. Bactericidal activity of mouse $\alpha$-defensin cryptdin-4 predominantly affects noncommensal bacteria. J Innate Immun 3: 315-326. [Medline] [CrossRef]

21. Akira S, Takeda K, Kaisho T. 2001. Toll-like receptors: critical proteins linking innate and acquired immunity. Nat Immunol 2: 675-680. [Medline] [CrossRef]

22. Akira S, Takeda K. 2004. Toll-like receptor signalling. Nat Rev Immunol 4: 499-511. [Medline] [CrossRef]

23. Szyk A, Wu Z, Tucker K, Yang D, Lu W, Lubkowski J. 2006. Crystal structures of human alpha-defensins HNP4, HD5, and HD6. Protein Sci 15: 2749-2760. [Medline] [CrossRef]

24. Pazgier M, Li X, Lu W, Lubkowski J. 2007. Human defensins: synthesis and structural properties. Curr Pharm Des 13: 3096-3118. [Medline] [CrossRef]

25. Jing W, Hunter HN, Tanabe H, Ouellette AJ, Vogel HJ. 2004. Solution structure of cryptdin-4, a mouse paneth cell alpha-defensin. Biochemistry 43: 15759-15766. [Medline] [CrossRef]

26. Selsted ME, Miller SI, Henschen AH, Ouellette AJ. 1992. Enteric defensins: antibiotic peptide components of intestinal host defense. J Cell Biol 118: 929-936. [Medline] [CrossRef]

27. Jones DE, Bevins CL. 1992. Paneth cells of the human small intestine express an antimicrobial peptide gene. J Biol Chem 267: 23216-23225. [Medline]

28. Wilson CL, Ouellette AJ, Satchell DP, Ayabe T, López-Boado YS, Stratman JL, Hultgren SJ, Matrisian LM, Parks WC. 1999. Regulation of intestinal alphadefensin activation by the metalloproteinase matrilysin in innate host defense. Science 286: 113-117. [Medline] [CrossRef]

29. Ghosh D, Porter E, Shen B, Lee SK, Wilk D, Drazba J, Yadav SP, Crabb JW, Ganz T, Bevins CL. 2002. Paneth cell trypsin is the processing enzyme for human defensin-5. Nat Immunol 3: 583-590. [Medline] [CrossRef]

30. Cunliffe RN, Rose FR, Keyte J, Abberley L, Chan WC, Mahida YR. 2001. Human defensin 5 is stored in precursor form in normal Paneth cells and is expressed by some villous epithelial cells and by metaplastic Paneth cells in the colon in inflammatory bowel disease. Gut 48: 176-185. [Medline] [CrossRef]

31. Tanabe H, Sato T, Watari J, Maemoto A, Fujiya M, Kono T, Ashida T, Ayabe T, Kohgo Y. 2008. Functional role of metaplastic paneth cell defensins in Helicobacter pylori-infected stomach. Helicobacter 13: 370-379. [Medline] [CrossRef]

32. Ayabe T, Satchell DP, Pesendorfer P, Tanabe H, Wilson CL, Hagen SJ, Ouellette AJ. 2002. Activation of Paneth cell $\alpha$-defensins in mouse small intestine. J Biol Chem 277: 5219-5228. [Medline] [CrossRef]

33. Maemoto A, Qu X, Rosengren KJ, Tanabe $\mathrm{H}$, 
Henschen-Edman A, Craik DJ, Ouellette AJ. 2004. Functional analysis of the $\alpha$-defensin disulfide array in mouse cryptdin-4. J Biol Chem 279: 44188-44196. [Medline] [CrossRef]

34. Tanabe H, Ayabe T, Bainbridge B, Guina T, Ernst RK, Darveau RP, Miller SI, Ouellette AJ. 2005. Mouse paneth cell secretory responses to cell surface glycolipids of virulent and attenuated pathogenic bacteria. Infect Immun 73: 2312-2320. [Medline] [CrossRef]

35. Ishikawa $\mathrm{C}$, Tanabe $\mathrm{H}$, Maemoto A, Ito $\mathrm{T}$, Watari J, Kono T, Fujiya M, Ashida T, Ayabe T, Kohgo Y. 2010. Precursor processing of human defensin-5 is essential to the multiple functions in vitro and in vivo. J Innate Immun 2: 66-76. [Medline] [CrossRef]

36. Tanabe H, Ouellette AJ, Cocco MJ, Robinson WE Jr. 2004. Differential effects on human immunodeficiency virus type 1 replication by alpha-defensins with comparable bactericidal activities. J Virol 78: 1162211631. [Medline] [CrossRef]

37. Satoh Y, Habara Y, Ono K, Kanno T. 1995. Carbamylcholine- and catecholamine-induced intracellular calcium dynamics of epithelial cells in mouse ileal crypts. Gastroenterology 108: 1345-1356. [Medline] [CrossRef]

38. Ayabe T, Wulff H, Darmoul D, Cahalan MD, Chandy KG, Ouellette AJ. 2002. Modulation of mouse Paneth cell alpha-defensin secretion by mIKCa1, a $\mathrm{Ca}^{2+}$-activated, intermediate conductance potassium channel. J Biol Chem 277: 3793-3800. [Medline] [CrossRef]

39. Vaishnava S, Behrendt CL, Ismail AS, Eckmann L, Hooper LV. 2008. Paneth cells directly sense gut commensals and maintain homeostasis at the intestinal host-microbial interface. Proc Natl Acad Sci USA 105: 20858-20863. [Medline] [CrossRef]

40. Bevins CL, Salzman NH. 2011. Paneth cells, antimicrobial peptides and maintenance of intestinal homeostasis. Nat Rev Microbiol 9: 356-368. [Medline] [CrossRef]

41. Hooper LV, Stappenbeck TS, Hong CV, Gordon JI. 2003. Angiogenins: a new class of microbicidal proteins involved in innate immunity. Nat Immunol 4: 269-273. [Medline] [CrossRef]

42. van Es JH, Jay $P$, Gregorieff A, van Gijn ME, Jonkheer S, Hatzis P, Thiele A, van den Born M, Begthel H, Brabletz T, Taketo MM, Clevers H. 2005. Wnt signalling induces maturation of Paneth cells in intestinal crypts. Nat Cell Biol 7: 381-386. [Medline] [CrossRef]

43. van der Flier LG, Clevers H. 2009. Stem cells, selfrenewal, and differentiation in the intestinal epithelium. Annu Rev Physiol 71: 241-260. [Medline] [CrossRef]

44. Stappenbeck TS. 2009. Paneth cell development, differentiation, and function: new molecular cues. Gastroenterology 137: 30-33. [Medline] [CrossRef]
45. Sato T, van Es JH, Snippert HJ, Stange DE, Vries RG, van den Born M, Barker N, Shroyer NF, van de Wetering M, Clevers H. 2011. Paneth cells constitute the niche for Lgr5 stem cells in intestinal crypts. Nature 469: 415-418. [Medline] [CrossRef]

46. Sato T, Vries RG, Snippert HJ, van de Wetering M, Barker N, Stange DE, van Es JH, Abo A, Kujala P, Peters PJ, Clevers H. 2009. Single Lgr5 stem cells build crypt-villus structures in vitro without a mesenchymal niche. Nature 459: 262-265. [Medline] [CrossRef]

47. Okamoto R, Tsuchiya K, Nemoto Y, Akiyama J, Nakamura T, Kanai T, Watanabe M. 2009. Requirement of Notch activation during regeneration of the intestinal epithelia. Am J Physiol Gastrointest Liver Physiol 296: G23-G35. [Medline] [CrossRef]

48. Ito T, Tanabe H, Ayabe T, Ishikawa C, Inaba $Y$, Maemoto A, Kono T, Ashida T, Fujiya M, Kohgo Y. 2012. Paneth cells regulate both chemotaxis of immature dendritic cells and cytokine production from epithelial cells. Tohoku J Exp Med 227: 39-48. [Medline] [CrossRef]

49. Yilmaz ÖH, Katajisto P, Lamming DW, Gültekin Y, Bauer-Rowe KE, Sengupta S, Birsoy K, Dursun A, Yilmaz VO, Selig M, Nielsen GP, Mino-Kenudson M, Zukerberg LR, Bhan AK, Deshpande V, Sabatini DM. 2012. mTORC1 in the Paneth cell niche couples intestinal stem-cell function to calorie intake. Nature 486: 490-495. [Medline]

50. Yang D, Biragyn A, Hoover DM, Lubkowski J, Oppenheim JJ. 2004. Multiple roles of antimicrobial defensins, cathelicidins, and eosinophil-derived neurotoxin in host defense. Annu Rev Immunol 22: 181-215. [Medline] [CrossRef]

51. Ayabe T, Ashida T, Kohgo Y, Kono T. 2004. The role of Paneth cells and their antimicrobial peptides in innate host defense. Trends Microbiol 12: 394-398. [Medline] [CrossRef]

52. Ouellette AJ. 2010. Paneth cells and innate mucosal immunity. Curr Opin Gastroenterol 26: 547-553. [Medline] [CrossRef]

53. Ouellette AJ. 2011. Paneth cell $\alpha$-defensins in enteric innate immunity. Cell Mol Life Sci 68: 2215-2229. [Medline] [CrossRef]

54. Salzman NH, Ghosh D, Huttner KM, Paterson Y, Bevins CL. 2003. Protection against enteric salmonellosis in transgenic mice expressing a human intestinal defensin. Nature 422: 522-526. [Medline] [CrossRef]

55. Brandl K, Plitas G, Schnabl B, DeMatteo RP, Pamer EG. 2007. MyD88-mediated signals induce the bactericidal lectin RegIII gamma and protect mice against intestinal Listeria monocytogenes infection. J Exp Med 204: 1891-1900. [Medline] [CrossRef]

56. Bouskra D, Brézillon C, Bérard M, Werts C, Varona R, Boneca IG, Eberl G. 2008. Lymphoid tissue genesis induced by commensals through NOD1 regulates intestinal homeostasis. Nature 456: 507-510. 
[Medline] [CrossRef]

57. Tsuji M, Suzuki K, Kinoshita K, Fagarasan S. 2008. Dynamic interactions between bacteria and immune cells leading to intestinal IgA synthesis. Semin Immunol 20: 59-66. [Medline] [CrossRef]

58. Hase K, Kawano K, Nochi T, Pontes GS, Fukuda S, Ebisawa M, Kadokura K, Tobe T, Fujimura Y, Kawano S, Yabashi A, Waguri S, Nakato G, Kimura S, Murakami T, Iimura M, Hamura K, Fukuoka S, Lowe AW, Itoh K, Kiyono H, Ohno H. 2009. Uptake through glycoprotein 2 of $\mathrm{FimH}(+)$ bacteria by $\mathrm{M}$ cells initiates mucosal immune response. Nature 462: 226-230. [Medline] [CrossRef]

59. Brown EM, Sadarangani M, Finlay BB. 2013. The role of the immune system in governing host-microbe interactions in the intestine. Nat Immunol 14: 660-667. [Medline] [CrossRef]

60. Hooper LV, Littman DR, Macpherson AJ. 2012. Interactions between the microbiota and the immune system. Science 336: 1268-1273. [Medline] [CrossRef]

61. Ivanov II, Honda K. 2012. Intestinal commensal microbes as immune modulators. Cell Host Microbe 12: 496-508. [Medline] [CrossRef]

62. Goto Y, Panea C, Nakato G, Cebula A, Lee C, Diez MG, Laufer TM, Ignatowicz L, Ivanov II. 2014. Segmented filamentous bacteria antigens presented by intestinal dendritic cells drive mucosal Th17 cell differentiation. Immunity 40: 594-607. [Medline] [CrossRef]

63. Atarashi K, Tanoue T, Shima T, Imaoka A, Kuwahara T, Momose Y, Cheng G, Yamasaki S, Saito T, Ohba Y, Taniguchi T, Takeda K, Hori S, Ivanov II, Umesaki Y, Itoh K, Honda K. 2011. Induction of colonic regulatory $\mathrm{T}$ cells by indigenous Clostridium species. Science 331: 337-341. [Medline] [CrossRef]

64. Atarashi K, Tanoue T, Oshima K, Suda W, Nagano Y, Nishikawa H, Fukuda S, Saito T, Narushima S, Hase K, Kim S, Fritz JV, Wilmes P, Ueha S, Matsushima K, Ohno H, Olle B, Sakaguchi S, Taniguchi T, Morita H, Hattori M, Honda K. 2013. Treg induction by a rationally selected mixture of Clostridia strains from the human microbiota. Nature 500: 232-236. [Medline] [CrossRef]

65. Furusawa Y, Obata Y, Fukuda S, Endo TA, Nakato G, Takahashi D, Nakanishi Y, Uetake C, Kato K, Kato T, Takahashi M, Fukuda NN, Murakami S, Miyauchi E, Hino S, Atarashi K, Onawa S, Fujimura Y, Lockett T, Clarke JM, Topping DL, Tomita M, Hori S, Ohara O, Morita T, Koseki H, Kikuchi J, Honda K, Hase K, Ohno H. 2013. Commensal microbe-derived butyrate induces the differentiation of colonic regulatory $\mathrm{T}$ cells. Nature 504: 446-450. [Medline] [CrossRef]

66. Vaishnava S, Yamamoto M, Severson KM, Ruhn KA, Yu X, Koren O, Ley R, Wakeland EK, Hooper LV. 2011. The antibacterial lectin RegIIIgamma promotes the spatial segregation of microbiota and host in the intestine. Science 334: 255-258. [Medline] [CrossRef]

67. Kato LM, Kawamoto S, Maruya M, Fagarasan S. 2014. The role of the adaptive immune system in regulation of gut microbiota. Immunol Rev 260: 67-75. [Medline] [CrossRef]

68. Kawamoto S, Maruya M, Kato LM, Suda W, Atarashi K, Doi Y, Tsutsui Y, Qin H, Honda K, Okada T, Hattori M, Fagarasan S. 2014. Foxp3(+) T cells regulate immunoglobulin a selection and facilitate diversification of bacterial species responsible for immune homeostasis. Immunity 41: 152-165. [Medline] [CrossRef]

69. Kawamoto S, Tran TH, Maruya M, Suzuki K, Doi Y, Tsutsui Y, Kato LM, Fagarasan S. 2012. The inhibitory receptor PD-1 regulates IgA selection and bacterial composition in the gut. Science 336: 485-489. [Medline] [CrossRef]

70. Hadjicharalambous C, Sheynis T, Jelinek R, Shanahan MT, Ouellette AJ, Gizeli E. 2008. Mechanisms of $\alpha$-defensin bactericidal action: comparative membrane disruption by Cryptdin-4 and its disulfide-null analogue. Biochemistry 47: 12626-12634. [Medline] [CrossRef]

71. Mastroianni JR, Ouellette AJ. 2009. $\alpha$-defensins in enteric innate immunity: functional Paneth cell $\alpha$-defensins in mouse colonic lumen. J Biol Chem 284: 27848-27856. [Medline] [CrossRef]

72. Mastroianni JR, Costales JK, Zaksheske J, Selsted ME, Salzman NH, Ouellette AJ. 2012. Alternative luminal activation mechanisms for paneth cell $\alpha$-defensins. J Biol Chem 287: 11205-11212. [Medline] [CrossRef]

73. Nakamura K, Sakuragi N, Ayabe T. 2013. A monoclonal antibody-based sandwich enzyme-linked immunosorbent assay for detection of secreted $\alpha$-defensin. Anal Biochem 443: 124-131. [Medline] [CrossRef]

74. Inaba $\mathrm{Y}$, Ashida $\mathrm{T}$, Ito $\mathrm{T}$, Ishikawa $\mathrm{C}$, Tanabe $\mathrm{H}$, Maemoto A, Watari J, Ayabe T, Mizukami Y, Fujiya M, Kohgo Y. 2010. Expression of the antimicrobial peptide alpha-defensin/cryptdins in intestinal crypts decreases at the initial phase of intestinal inflammation in a model of inflammatory bowel disease, IL-10deficient mice. Inflamm Bowel Dis 16: 1488-1495. [Medline] [CrossRef]

75. Turnbaugh PJ, Ley RE, Mahowald MA, Magrini V, Mardis ER, Gordon JI. 2006. An obesity-associated gut microbiome with increased capacity for energy harvest. Nature 444: 1027-1031. [Medline] [CrossRef]

76. Ley RE. 2010. Obesity and the human microbiome. Curr Opin Gastroenterol 26: 5-11. [Medline] [CrossRef]

77. Qin J, Li Y, Cai Z, Li S, Zhu J, Zhang F, Liang S, Zhang W, Guan Y, Shen D, Peng Y, Zhang D, Jie Z, Wu W, Qin Y, Xue W, Li J, Han L, Lu D, Wu P, Dai Y, Sun X, Li Z, Tang A, Zhong S, Li X, Chen W, Xu R, Wang M, Feng Q, Gong M, Yu J, Zhang Y, Zhang M, Hansen 
T, Sanchez G, Raes J, Falony G, Okuda S, Almeida M, LeChatelier E, Renault P, Pons N, Batto JM, Zhang Z, Chen H, Yang R, Zheng W, Li S, Yang H, Wang J, Ehrlich SD, Nielsen R, Pedersen O, Kristiansen K, Wang J. 2012. A metagenome-wide association study of gut microbiota in type 2 diabetes. Nature 490: 55-60. [Medline] [CrossRef]

78. Vijay-Kumar M, Aitken JD, Carvalho FA, Cullender TC, Mwangi S, Srinivasan S, Sitaraman SV, Knight R, Ley RE, Gewirtz AT. 2010. Metabolic syndrome and altered gut microbiota in mice lacking Toll-like receptor 5. Science 328: 228-231. [Medline] [CrossRef]

79. Tremaroli V, Bäckhed F. 2012. Functional interactions between the gut microbiota and host metabolism. Nature 489: 242-249. [Medline] [CrossRef]

80. Karlsson FH, Fåk F, Nookaew I, Tremaroli V, Fagerberg B, Petranovic D, Bäckhed F, Nielsen J. 2012. Symptomatic atherosclerosis is associated with an altered gut metagenome. Nat Commun 3: 1245. [CrossRef] [Medline]

81. Abu-Shanab A, Quigley EM. 2010. The role of the gut microbiota in nonalcoholic fatty liver disease. Nat Rev Gastroenterol Hepatol 7: 691-701. [Medline] [CrossRef]

82. Henao-Mejia J, Elinav E, Jin C, Hao L, Mehal WZ, Strowig T, Thaiss CA, Kau AL, Eisenbarth SC, Jurczak MJ, Camporez JP, Shulman GI, Gordon JI, Hoffman HM, Flavell RA. 2012. Inflammasome-mediated dysbiosis regulates progression of NAFLD and obesity. Nature 482: 179-185. [Medline]

83. Hsiao EY, McBride SW, Hsien S, Sharon G, Hyde ER, McCue T, Codelli JA, Chow J, Reisman SE, Petrosino JF, Patterson PH, Mazmanian SK. 2013. Microbiota modulate behavioral and physiological abnormalities associated with neurodevelopmental disorders. Cell 155: 1451-1463. [Medline] [CrossRef]

84. Qin N, Yang F, Li A, Prifti E, Chen Y, Shao L, Guo J, Le Chatelier E, Yao J, Wu L, Zhou J, Ni S, Liu L, Pons N, Batto JM, Kennedy SP, Leonard P, Yuan C, Ding W, Chen Y, Hu X, Zheng B, Qian G, Xu W, Ehrlich SD, Zheng S, Li L. 2014. Alterations of the human gut microbiome in liver cirrhosis. Nature 513: 59-64. [Medline] [CrossRef]

85. Yoshimoto S, Loo TM, Atarashi K, Kanda H, Sato S, Oyadomari S, Iwakura Y, Oshima K, Morita H, Hattori M, Honda K, Ishikawa Y, Hara E, Ohtani N. 2013. Obesity-induced gut microbial metabolite promotes liver cancer through senescence secretome. Nature 499: 97-101. [Medline] [CrossRef]

86. Manichanh C, Rigottier-Gois L, Bonnaud E, Gloux K, Pelletier E, Frangeul L, Nalin R, Jarrin C, Chardon P, Marteau P, Roca J, Dore J. 2006. Reduced diversity of faecal microbiota in Crohn's disease revealed by a metagenomic approach. Gut 55: 205-211. [Medline] [CrossRef]

87. Gevers D, Kugathasan S, Denson LA, Vázquez-Baeza
Y, Van Treuren W, Ren B, Schwager E, Knights D, Song SJ, Yassour M, Morgan XC, Kostic AD, Luo C, González A, McDonald D, Haberman Y, Walters T, Baker S, Rosh J, Stephens M, Heyman M, Markowitz J, Baldassano R, Griffiths A, Sylvester F, Mack D, Kim S, Crandall W, Hyams J, Huttenhower C, Knight R, Xavier RJ. 2014. The treatment-naive microbiome in new-onset Crohn's disease. Cell Host Microbe 15: 382-392. [Medline] [CrossRef]

88. Kostic AD, Xavier RJ, Gevers D. 2014. The microbiome in inflammatory bowel disease: current status and the future ahead. Gastroenterology 146: 1489-1499. [Medline] [CrossRef]

89. Couturier-Maillard A, Secher T, Rehman A, Normand S, De Arcangelis A, Haesler R, Huot L, Grandjean T, Bressenot A, Delanoye-Crespin A, Gaillot O, Schreiber S, Lemoine Y, Ryffel B, Hot D, Nùñez G, Chen G, Rosenstiel P, Chamaillard M. 2013. NOD2-mediated dysbiosis predisposes mice to transmissible colitis and colorectal cancer. J Clin Invest 123: 700-711. [Medline]

90. Fujimura KE, Lynch SV. 2015. Microbiota in allergy and asthma and the emerging relationship with the gut microbiome. Cell Host Microbe 17: 592-602. [Medline] [CrossRef]

91. Kelly CR, Kahn S, Kashyap P, Laine L, Rubin D, Atreja A, Moore T, Wu G. 2015. Update on fecal microbiota transplantation 2015: indications, methodologies, mechanisms, and outlook. Gastroenterology 149: 223-237. [Medline] [CrossRef]

92. Sadlack B, Merz H, Schorle H, Schimpl A, Feller AC, Horak I. 1993. Ulcerative colitis-like disease in mice with a disrupted interleukin-2 gene. Cell 75: 253-261. [Medline] [CrossRef]

93. Schultz M, Tonkonogy SL, Sellon RK, Veltkamp C, Godfrey VL, Kwon J, Grenther WB, Balish E, Horak I, Sartor RB. 1999. IL-2-deficient mice raised under germfree conditions develop delayed mild focal intestinal inflammation. Am J Physiol 276: G1461G1472. [Medline]

94. Kühn R, Löhler J, Rennick D, Rajewsky K, Müller W. 1993. Interleukin-10-deficient mice develop chronic enterocolitis. Cell 75: 263-274. [Medline] [CrossRef]

95. Sartor RB. 2008. Microbial influences in inflammatory bowel diseases. Gastroenterology 134: 577-594. [Medline] [CrossRef]

96. Hugot JP, Chamaillard M, Zouali H, Lesage S, Cézard JP, Belaiche J, Almer S, Tysk C, O’Morain CA, Gassull M, Binder V, Finkel Y, Cortot A, Modigliani R, LaurentPuig P, Gower-Rousseau C, Macry J, Colombel JF, Sahbatou M, Thomas G. 2001. Association of NOD2 leucine-rich repeat variants with susceptibility to Crohn's disease. Nature 411: 599-603. [Medline] [CrossRef]

97. Ogura Y, Bonen DK, Inohara N, Nicolae DL, Chen FF, Ramos R, Britton H, Moran T, Karaliuskas R, Duerr 
RH, Achkar JP, Brant SR, Bayless TM, Kirschner BS, Hanauer SB, Nuñez G, Cho JH. 2001. A frameshift mutation in NOD2 associated with susceptibility to Crohn's disease. Nature 411: 603-606. [Medline] [CrossRef]

98. Kobayashi KS, Chamaillard M, Ogura Y, Henegariu O, Inohara N, Nuñez G, Flavell RA. 2005. Nod2dependent regulation of innate and adaptive immunity in the intestinal tract. Science 307: 731-734. [Medline] [CrossRef]

99. McGuckin MA, Eri RD, Das I, Lourie R, Florin TH. 2010. ER stress and the unfolded protein response in intestinal inflammation. Am J Physiol Gastrointest Liver Physiol 298: G820-G832. [Medline] [CrossRef]

100. Salzman NH, Underwood MA, Bevins CL. 2007. Paneth cells, defensins, and the commensal microbiota: a hypothesis on intimate interplay at the intestinal mucosa. Semin Immunol 19: 70-83. [Medline] [CrossRef]

101. Cadwell K, Liu JY, Brown SL, Miyoshi H, Loh J, Lennerz JK, Kishi C, Kc W, Carrero JA, Hunt S, Stone CD, Brunt EM, Xavier RJ, Sleckman BP, Li E, Mizushima N, Stappenbeck TS, Virgin HW 4th. 2008. A key role for autophagy and the autophagy gene Atg1611 in mouse and human intestinal Paneth cells. Nature 456: 259-263. [Medline] [CrossRef]

102. Cadwell K, Patel KK, Maloney NS, Liu TC, Ng AC, Storer CE, Head RD, Xavier R, Stappenbeck TS, Virgin HW 4th. 2010. Virus-plus-susceptibility gene interaction determines Crohn's disease gene Atg16L1 phenotypes in intestine. Cell 141: 1135-1145. [Medline] [CrossRef]

103. Kaser A, Lee AH, Franke A, Glickman JN, Zeissig S, Tilg H, Nieuwenhuis EE, Higgins DE, Schreiber S, Glimcher LH, Blumberg RS. 2008. XBP1 links ER stress to intestinal inflammation and confers genetic risk for human inflammatory bowel disease. Cell 134: 743-756. [Medline] [CrossRef]

104. Park SW, Zhen G, Verhaeghe C, Nakagami Y, Nguyenvu LT, Barczak AJ, Killeen N, Erle DJ. 2009. The protein disulfide isomerase AGR2 is essential for production of intestinal mucus. Proc Natl Acad Sci USA 106: 6950-6955. [Medline] [CrossRef]

105. Zhao F, Edwards R, Dizon D, Afrasiabi K, Mastroianni JR, Geyfman M, Ouellette AJ, Andersen B, Lipkin SM. 2010. Disruption of Paneth and goblet cell homeostasis and increased endoplasmic reticulum stress in Agr2-/mice. Dev Biol 338: 270-279. [Medline] [CrossRef]

106. Grootjans J, Hodin CM, de Haan JJ, Derikx JP, Rouschop KM, Verheyen FK, van Dam RM, Dejong $\mathrm{CH}$, Buurman WA, Lenaerts K. 2011. Level of activation of the unfolded protein response correlates with Paneth cell apoptosis in human small intestine exposed to ischemia/reperfusion. Gastroenterology
140: 529-539.e3. [Medline] [CrossRef]

107. Simms LA, Doecke JD, Walsh MD, Huang N, Fowler EV, Radford-Smith GL. 2008. Reduced alpha-defensin expression is associated with inflammation and not NOD2 mutation status in ileal Crohn's disease. Gut 57: 903-910. [Medline] [CrossRef]

108. Tanabe H, Ayabe T, Maemoto A, Ishikawa C, Inaba Y, Sato R, Moriichi K, Okamoto K, Watari J, Kono T, Ashida T, Kohgo Y. 2007. Denatured human $\alpha$-defensin attenuates the bactericidal activity and the stability against enzymatic digestion. Biochem Biophys Res Commun 358: 349-355. [Medline] [CrossRef]

109. Shanahan MT, Vidrich A, Shirafuji Y, Dubois CL, Henschen-Edman A, Hagen SJ, Cohn SM, Ouellette AJ. 2010. Elevated expression of Paneth cell CRS4C in ileitis-prone SAMP1/YitFc mice: regional distribution, subcellular localization, and mechanism of action. J Biol Chem 285: 7493-7504. [Medline] [CrossRef]

110. Eriguchi Y, Takashima S, Oka H, Shimoji S, Nakamura K, Uryu H, Shimoda S, Iwasaki H, Shimono N, Ayabe T, Akashi K, Teshima T. 2012. Graft-versushost disease disrupts intestinal microbial ecology by inhibiting Paneth cell production of $\alpha$-defensins. Blood 120: 223-231. [Medline] [CrossRef]

111. Eriguchi Y, Uryu H, Nakamura K, Shimoji S, Takashima S, Iwasaki H, Miyamoto $\mathrm{T}$, Shimono N, Hashimoto D, Akashi K, Ayabe T, Teshima T. 2013. Reciprocal expression of enteric antimicrobial proteins in intestinal graft-versus-host disease. Biol Blood Marrow Transplant 19: 1525-1529. [Medline] [CrossRef]

112. Eriguchi Y, Nakamura K, Hashimoto D, Shimoda S, Shimono N, Akashi K, Ayabe T, Teshima T. 2015. Decreased secretion of Paneth cell $\alpha$-defensins in graftversus-host disease. Transpl Infect Dis 17: 702-706. [CrossRef] [Medline]

113. Hodin CM, Verdam FJ, Grootjans J, Rensen SS, Verheyen FK, Dejong CH, Buurman WA, Greve JW, Lenaerts K. 2011. Reduced Paneth cell antimicrobial protein levels correlate with activation of the unfolded protein response in the gut of obese individuals. J Pathol 225: 276-284. [Medline] [CrossRef]

114. Raetz M, Hwang SH, Wilhelm CL, Kirkland D, Benson A, Sturge CR, Mirpuri J, Vaishnava S, Hou B, Defranco AL, Gilpin CJ, Hooper LV, Yarovinsky F. 2013. Parasite-induced TH1 cells and intestinal dysbiosis cooperate in IFN- $\gamma$-dependent elimination of Paneth cells. Nat Immunol 14: 136-142. [Medline] [CrossRef]

115. Nakamura K, Ayabe T. 2012. Paneth cells and stem cells in the intestinal stem cell niche and their association with inflammatory bowel disease. Inflammation Regeneration 32: 53-60. [CrossRef] 